\title{
A Silyl Carbamate Linker for Solid-State Peptide Synthesis in the Reverse Direction
}

Peptide Chemistry

\section{Key words}

silyl carbamates

linking group

solid phase synthesis

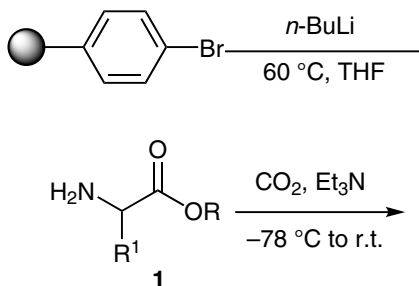

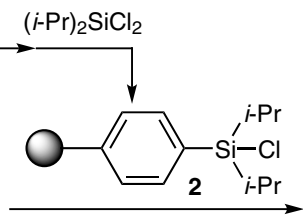<smiles>CCNC(Cc1ccccc1)C(=O)OC</smiles>

polypeptides

Selected examples:

Q<smiles>COC(=O)[C@H](Cc1ccccc1)NC(=O)O[Si](C(=O)OC)(C(C)=P)c1ccc(I)cc1</smiles>

3a, $76 \%$ yield $^{\mathrm{a}}$

1 a, $82 \%$ yield ${ }^{b}$ 3b, $85 \%$ yield ${ }^{\mathrm{C}}$

1b, $89 \%$ yield $^{b}$

Q<smiles>COC(=O)C(Cc1ccccc1)NC(=O)O[Si](C(=O)O)(c1ccc(C)cc1)C(C)C</smiles><smiles>CCC[Si](OC(=O)N1CCCC1C(=O)O)(c1ccc(O)cc1)C(C)C</smiles>

3c, $93 \%$ yield ${ }^{C}$

${ }^{a}$ Yield determined by elemental analysis. ${ }^{b}$ Isolated yield. ${ }^{c}$ Yield determine based on resin gain in weight

Application of silyl linker in solid phase peptide synthesis in reverse direction:

$$
\text { 3b/3c } \underset{\substack{\left.10 \% \mathrm{Pd}_{2} \mathrm{Ph}_{3} \mathrm{P}\right)_{4} \\ \mathrm{Me}_{2} \mathrm{NH} \mathrm{BH}_{3}}}{190 \% \text { yield }}
$$

Selected examples:<smiles>O=C(N[C@@H](Cc1ccccc1)C(=O)NC(Cc1ccccc1)C(=O)OCc1ccccc1)Oc1ccccc1</smiles>

$75 \%$ yield<smiles>CC(=O)C(NC(=O)C1CCCN1C(=O)c1ccccc1)c1ccccc1</smiles>

$92 \%$ yield<smiles>CCCCC[C@H](NC(=O)[C@@H]1CCCN1C(=O)OCc1ccccc1)C(C)=O</smiles>

$84 \%$ yield
Significance: Silicon-containing solid supports play an inherent role in solid-state peptide synthesis. Consequently, chemists are in search of elegant and practical supports for peptide synthesis. In 2001, Lipshutz and Shin developed a novel and easily accessible silyl carbamate linker for peptide synthesis.
Comment: Polystyrene-bound silyl carbamates of amino acid esters were synthesized by treatment of amino acid esters with gaseous $\mathrm{CO}_{2}$ in dichloromethane, with subsequent trapping of the polymer-bound silyl chloride. The resulting polystyrene-bound silyl carbamates of amino acid esters can be used in solid-state syntheses of polypeptides, building from the carboxy terminus. 